\title{
Customer loyalty in the South African long-term insurance industry
}

\begin{abstract}
Authors:
Leon du Plessis ${ }^{1}$

Mornay Roberts-Lombard ${ }^{2}$

Affiliations:

${ }^{1}$ Department of Business

Management, University of

Johannesburg, South Africa

${ }^{2}$ Department of Marketing Management, University of Johannesburg, South Africa
\end{abstract}

Correspondence to:

Mornay Roberts-Lombard

Email:

mornayrl@uj.ac.za

Postal address:

Department of Marketing

Management, C-Ring 607,

Kingsway campus, Auckland

Park 2006, South Africa

Dates:

Received: 04 Jan. 2012

Accepted: 21 Aug. 2012

Published: 29 Apr. 2013

Republished: 30 Jan. 2014

How to cite this article:

Du Plessis, L. \& Roberts-

Lombard, M., 2013,

'Customer loyalty in the

South African long-term

insurance industry', Acto

Commercii 13(1), Art. \#167,

8 pages. http://dx.doi.

org/10.4102/ac.v13i1.167

Note:

Permission was granted by the African Journal of Business Management to publish this article in part, as it is based on the same methodology used in the previously published work of Roberts-Lombard in this journal.

Article republished with the correct affiliation for Leon du Plessis.

\section{Copyright:}

(C) 2013. The Authors.

Licensee: AOSIS

OpenJournals. This work

is licensed under the

Creative Commons

Attribution License.

\section{Read online:}

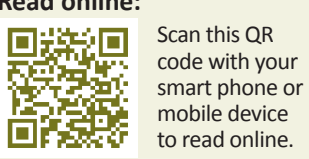

The primary objective of this study is to investigate the influence of selected independent variables, two-way communication and conflict handling on intentional customer loyalty via Customer Relationship Management (CRM) as the intervening variable within the South African long-term insurance environment. Primary data were gathered using a questionnaire, with items referring to Customer Relationship Management, customer loyalty, two-way communication and conflict handling. The sample consisted of 254 customers in four customer walk-in centres of a long-term insurance provider in South Africa. Data were factor-analysed. One independent variable, conflict handling, exerted a statistically significant positive influence on the intervening variable (CRM), whilst two-way communication exerted a statistically significant negative influence on the intervening variable. This variable (CRM) positively influenced the dependent variable (customer loyalty). If long-term insurance organisations communicate timeously and accurately, and are skilled in conflict handling, greater loyalty will be created amongst customers. The study revealed that the majority of customers $(51.53 \%)$ strongly agree that two-way communication is an important dimension that underpins Customer Relationship Management and their relationship with a long-term insurance organisation. The empirical results indicate a negative relationship between the perceived two-way communication by a long-term insurance organisation and CRM at the insurance provider in South Africa. In terms of conflict handling, the study revealed that the majority of customers (45.69\%) strongly agree that conflict handling is an important dimension that underpins Customer Relationship Management and their relationship with a longterm insurance organisation. The empirical results indicate a positive relationship between perceived conflict handling by a long-term insurance provider and CRM at the organisation in South Africa. Finally, the empirical results indicate a positive relationship between Customer Relationship Management and intentional customer loyalty at a long-term insurance provider in South Africa.

\section{Introduction}

Over the past 20 years, the importance of the service industries to the world economy has grown tremendously. In the South African economy the contribution of the service sector to the country's Gross Domestic Product (GDP) has increased from 45.6\% (1980) to 65.9\% (2000), to a very high percentage of 75.6\% in 2010 (Datamonitor 2011a; Rootman 2011:1). In South Africa, the service sector is expected to continue its growth at an accelerated rate in the future (Rootman 2011:1). The services sector, which employs $72 \%$ of the total workforce in South Africa, is spearheaded by the financial services sector. The South African insurance market generated total gross written premiums of $\$ 24.2$ billion in 2007 , which increased to $\$ 26.9$ billion in 2010 . This growth represents a compound annual growth rate (CAGR) of $8.99 \%$ for the period spanning 2007-2010. The performance of the market is forecast to accelerate, with an anticipated CAGR of $9.7 \%$ for the fiveyear period from 2007-2012, which is expected to drive the market to a value of approximately $\$ 30$ billion by the end of 2012 (Datamonitor 2011b).

A business that wants to succeed in today's global competitive market, where customers are empowered and brand loyalty erosion is increasing, will have to move to Customer Relationship Management, hereafter referred to as CRM. CRM enables organisations to provide excellent realtime customer service through the effective use of individual account information (Kotler and Keller 2006:152). This requires a more complex approach because of the fact that organisations need to both investigate and satisfy their customers' needs, and have to build relationships with both existing and potential customers (Rootman 2006:2). Long-term insurance organisations will therefore require a loyal customer base in order to secure their sustainability. Loyal customers can be generated through CRM, which can assist long-term insurance organisations in building longterm beneficial relationships with customers. This has a direct influence on the value proposition to customers and on the competitive position of the organisation in the market, and will lead to 
customer loyalty and increased profits for the organisation (Strachan \& Roberts-Lombard 2010:3488-3489).

Relationship Marketing and its application, CRM, focus on the long-term profitability of keeping customers for life (Sauers 2008:xxi). This requires two-way dialogue between the organisation and the customer in order to develop a relationship (Du Plessis, Jooste \& Strydom 2005:73). The literature stipulates that two-way communication and conflict handling form important parts of CRM. Communication is very important, especially in the early stages of the relationship with the customer, as an organisation wants to build awareness and convince interested customers to make a purchase. Communication is the ability to provide timely and trustworthy information (Ndubisi 2007:100). If an organisation succeeds in avoiding or resolving conflicts with customers before they become problems, this will have a positive influence on customer loyalty (Ndubisi \& Wah 2005:553). However, it remains important to consider the argument above within the context of the Service Dominant Logic (S-D) paradigm. This paradigm defines service as the application of competency through deeds, processes and performances for the benefit of another entity or the entity itself. It leverages the strengths of the organisation to satisfy customer needs and achieve organisational and societal objectives. The unique matching of organisational capabilities with customer needs, guided by an on-going conversation between them, generates long-term customer loyalty and competitive advantage (Lusch \& Vargo 2011:1299; Vargo 2011:218-219).

This article includes a literature review of the S-D paradigm, CRM and customer loyalty, and an explanation of the problem that was investigated. The research objectives, hypotheses and methodology are then discussed. Thereafter, the empirical results are discussed, followed by management implications and recommendations.

\section{Literature review}

The Relationship Marketing (RM) concept has received much attention over the last decade since it encompasses a longterm focus on marketing. The assumption that underlies RM is the establishment and maintenance of relationships with customers that will secure customer loyalty, customer share development and increased profits and recovery should problems occur (Ward \& Dagger 2007:281). RM focuses on the necessity to establish and maintain relationships between the customer and the seller (Iglesias, Sauquet \& Montana 2011:632). Terblanche (2003:28) states that the purpose of RM is to enhance marketing productivity by achieving efficiency and effectiveness, since relationship marketers believe that interdependence reduces transaction costs and generates higher quality, whilst keeping governance costs lower than would exchange marketing. RM is applied in the organisation through the implementation of Customer Relationship Management (CRM) processes, with a focus on the longterm profitability in the event of keeping customers for life (Sauers 2008:xxi). CRM is an organisation-wide commitment to identify the individual customers of an organisation, and to create a mutually beneficial relationship between the organisation and the customer. CRM evolved from RM because of the growing emphasis on improved customer retention and loyalty through the management of customer relationships (Berndt et al. 2009:237-238; Ndubisi 2007:98). CRM is not simply a method used by an organisation to gain a competitive advantage; it has become a necessity for its survival (Berndt et al. 2009:236; Buttle 2004:ix).

\section{Customer relationship management}

$\mathrm{CRM}$ is increasingly being recognised as a strategic approach to developing marketing relationships with individual customers. It requires some form of response from the potential customers so that the organisation is enabled to take action (Harwood, Garry \& Broderick 2008:31). CRM is concerned with coordinating activities necessary to establish and maintain long-term profitable, mutually-beneficial customer relationships. As a strategy, CRM focus on the different resources available for the building and maintenance of relationships as well as maintenance efforts that should be allocated according to an individual customer's potential lifetime value to the organisation (Robinson, Neeley \& Williamson 2011:91). Fuxiang and Yuhui (2011:3) state that CRM is a customer-centric strategy that focuses on increasing loyalty and productivity through an understanding of the evolutionary needs of customers.

Hasouneh \& Alqeed (2010:51-52) state that organisations adopt CRM strategies for both defensive and offensive reasons. Offensive arguments are associated with a desire to improve profitability by reducing costs and increasing revenues through improved customer satisfaction and loyalty. Defensive arguments apply when an organisation's leading competitors have adopted CRM successfully, and it fears losing customers and revenue. The primary reasons for organisations wanting to build relationships with customers are based on economic considerations. Organisations generate better results when they manage their customer base in such a manner that they can identify, satisfy and retain their most profitable customers. The reason for the implementation of CRM strategies is therefore that it improves business performance by enhancing customer satisfaction and increasing customer loyalty (Rootman 2006:4).

\section{Two important components of customer relationship management}

Prior studies have identified two underpinnings of RM that are of importance in a service-related environment, namely communication (Rootman 2011:25; Ndubisi \& Chan 2005:563; Morgan \& Hunt 1994:25) and conflict handling (Ndubisi \& Chan 2005:564). These underpinnings have been linked to customer loyalty in the study.

\section{Two-way communication}

The focus of CRM is on attracting and retaining customers through cooperation and the sharing of information between 
the parties in the relationship. In the ongoing relationship with the customer the organisation is required to communicate with the customer, and the customer is expected to listen. CRM requires that both parties in a relationship communicate with each other (Hakkio \& Laaksonen 1998:217-218). Rootman (2011:185) states that communication is not only about conveying a message, but that there also needs to be an understanding between the parties involved in order for the communication to be effective. Communication should inform a dissatisfied customer as to what the organisation is doing to rectify the source of dissatisfaction. It is for this reason that two-way communication is important within the CRM process, since customers want to be heard and not just promoted to (Rootman 2006:78-79). Strachan (2010:49) concur with this statement by arguing that customers need to trust that if they have a problem, they are able to communicate this with the organisation without the possibility of negative reactions. The organisation too needs to trust that they can be honest and communicate any updates or news, be it positive or negative, with the customer. Should trust be present, the communication of any negative aspects or situations is more likely to result in positive and understanding reactions.

\section{Conflict handling}

Ndubisi \& Wah (2005:546) refer to conflict handling as the ability of an organisation to reduce the negative consequences of potential conflicts. Conflict handling encompasses the ability of the organisation to avoid potential conflict scenarios, to resolve manifest conflicts prior to their creating problems, and the ability to discuss solutions in an open manner when problems do arise. The manner in which conflicts are managed will ensure loyalty, exit or voice. Strachan (2010:51) also states that whether an individual will be involved in such behaviours will depend on the degree of prior satisfaction with the relationship, the magnitude of the person's investment in the relationship and an evaluation of the alternatives to which the individual has recourse.

Conflict handling is the restoration and strengthening of a long-term relationship with a customer. The action taken must be constructive; it should not be only mechanical or routine. Customers do not always have to be delighted to remain loyal, but they have to be compensated for the actual loss which they suffered, and they must perceive that they were treated fairly. A single negative experience, properly settled, will not make customers defect (Wu 2011:35-36). Conflict handling systems can give an organisation a competitive advantage as the organisations encourage listening and learning through this process. Conflict handling systems should not be so formalistic as to deter learning and improvement. A conflict handling system is one of the best ways to collect customer intelligence (Egan 2004:143; Gummesson 2003:88).

\section{Customer loyalty}

Hasouneh and Alqeed (2010:51) refer to customer loyalty as the degree to which customers are predisposed to stay with an organisation and resist competitive offers. As a measure, customer loyalty is the proportion of times a purchaser chooses the same product or service in a specific category compared to the total number of purchases made by the purchaser in that category. Whilst relationships are a central part of loyalty, they alone are not enough to make a customer loyal. Botes (2008:15) argues that customer loyalty does not occur at once - it is a long-term process but customer satisfaction can occur immediately following a successful process. Satisfaction is a necessary step in loyalty formation and satisfaction becomes less significant as loyalty begins to set in through other mechanisms such as personal determinism and social bonding (Toriani \& Angeloni 2011:93). To keep customers loyal they must be satisfied. Failure by organisations to meet the expectation of customers will lead to dissatisfaction with the product or service, as customer loyalty flows from customer satisfaction (Zeithaml, Bitner \& Gremler 2006:110). However, Ndubisi and Wah (2005:546) state that a customer who has enjoyed good service delivery in the past is more likely to believe that the service failure is a deviation from the norm. Therefore, it is argued that an unsatisfactory incident alone would not motivate strongly loyal customers to change their perceptions of the organisation or to consider switching to another supplier.

\section{Problem statement}

Statistics released by the Life Offices Association (2007) indicate that in the second half of 2006 the surrender of policies increased. Lapsed premiums also increased by $18 \%$ as compared to the previous half-year, and by $31 \%$ compared to the corresponding period in 2005. A policy is surrendered when the policyholder stops paying the premiums and withdraws the reduced fund value of the policy before maturity. A lapse occurs when the policyholder stops paying premiums before the fund value exceeds the unrecovered costs, meaning that the paid-up or surrender value is zero. In both cases, customers are lost as they terminate their relationship with the long-term insurance organisation. The purpose of CRM is to increase customer satisfaction, improve customer perception of service quality and increase customer loyalty (Baran, Galka \& Strunk 2008:397). CRM, applied correctly, leads to customer loyalty, and loyal customers are usually more profitable (Grönroos 2003:7).

To retain existing customers in the current economic climate where customers are allowing their long-term insurance policies to lapse because of the unsure economic future, long-term insurance organisations will have to understand how two-way communication and conflict handling through the application of CRM can contribute to customer loyalty. Larger portions of long-term customers, rather than shortterm customers, exhibit high profitability, therefore the theory of an overall positive connection between customer loyalty and profitability cannot be rejected (Leverin \& Liljander 2006:235). Long-term insurance organisations will not be able to survive for much longer in the competitive long-term insurance industry, battling the global recession, if they do not understand the importance of these two variables influencing their CRM and how they can improve customer loyalty. This article will focus on the importance for long-term insurance organisations to better understand 
the need for CRM and how that will lead to customer loyalty. The problem statement therefore refers to an investigation of the influence of the variables (two-way communication and conflict handling) on customer loyalty though the intervening role of CRM at a long-term insurance organisation in South Africa.

Figure 1 illustrates that the independent variables of the research constitute selected variables as identified in literature on CRM. These variables are two-way communication and conflict handling. In this article, each variable's influence was assessed through an empirical investigation. The article will further attempt to identify the degree of influence of CRM on the customer loyalty of a long-term insurance organisation in South Africa. The dependent variable, customer loyalty, refers to the impact of the underpinnings of CRM on customer loyalty.

\section{Research objectives}

The primary objective of this article is to investigate the influence of the independent variables, two-way communication and conflict handling on intentional customer loyalty via CRM as the intervening variable at a long-term insurance organisation in South Africa. The primary objective is supported by the following secondary objectives:

- To investigate whether two-way communication influences CRM at a long-term insurance organisation in South Africa.

- To investigate the influence of conflict handling on CRM at a long-term insurance organisation in South Africa.

- To investigate the relationship between CRM and intentional customer loyalty at a long-term insurance organisation in South Africa.

\section{Research hypotheses}

To give effect to the problem statement, a number of null hypotheses were formulated, stating that no relationships

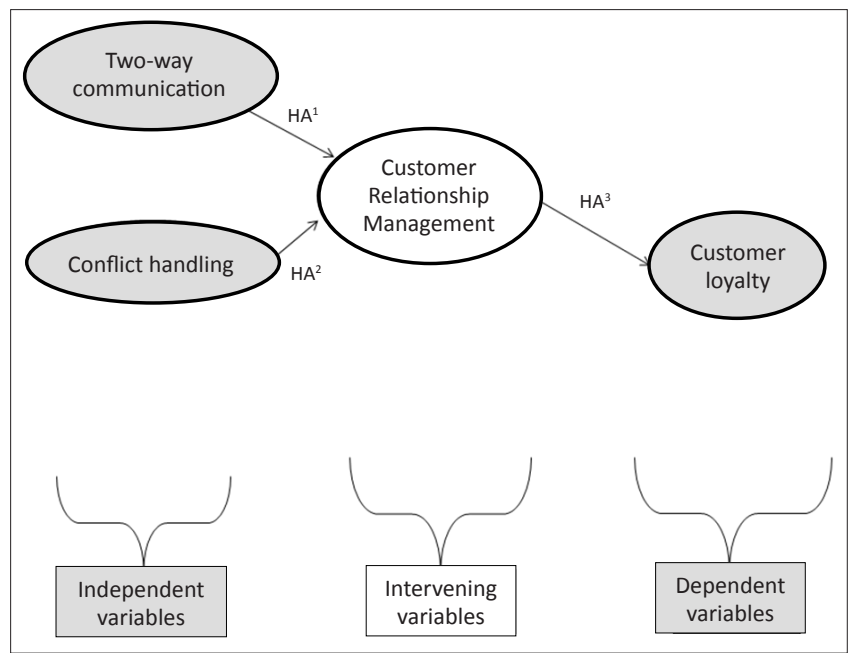

Source: Developed for this research

FIGURE 1: Conceptual framework. exist. Alternative hypotheses were also formulated stating that the relationships do exist.

\section{Relationship between the independent variables and the intervening variable, customer relationship management}

$\mathrm{HO}^{1}$ : There is no relationship between perceived twoway communication and CRM at a long-term insurance organisation in South Africa.

$\mathrm{HA}^{1}$ : There is a relationship between perceived twoway communication and CRM at a long-term insurance organisation in South Africa.

$\mathrm{HO}^{2}$ : There is no relationship between perceived conflict handling and CRM at a long-term insurance organisation in South Africa.

$\mathrm{HA}^{2}$ : There is a relationship between perceived conflict handling and a long-term insurance organisation in South Africa.

\section{Relationship between the intervening variable, customer relationship management, and the dependent variable, customer loyalty}

$\mathrm{HO}^{3}$ : There is no relationship between CRM and intentional customer loyalty at a long-term insurance organisation in South Africa.

$\mathrm{HA}^{3}$ : There is a relationship between CRM and intentional customer loyalty at a long-term insurance organisation in South Africa.

\section{Research methodology}

The population of the study encompassed the individual long-term insurance policy holders of a life insurer whose customers visited the different walk-in centres of the insurer. Probability sampling was used in the study. A stratified sampling technique was applied since the sampling frame of the study was divided into different strata, namely the four cities where the Customer Walk-in-Centres of the life insurer are located. The sample size of this study consisted of 254 customers. An interviewer-administered survey was used to collect data from respondents. Structured questions were used to elicit responses. The questionnaire consisted of 7-point Likert-type scale statements measuring twoway communication, conflict handling, CRM and customer loyalty. Multiple regression analysis was performed to assess the relationship between two-way communication, conflict handling and CRM as well as the relationship between CRM and customer loyalty.

\section{Findings}

The findings of the empirical investigation are presented in the following section. To start with, this article will look at reliability, next validity, and lastly the findings of the multiple regression analyses will be discussed. 


\section{Reliability}

The internal consistency reliability test compares different samples of the items being used to measure a phenomenon, during the same time period. This can be done by means of a split-half reliability test, also known as the coefficient alpha or Cronbach's alpha, and results exceeding 0.70 will reflect the lower level of acceptability (Hair et al. 1998:118). The reliability statistics for the questionnaire are presented in Table 1.

It is evident from the data in Table 1 that Cronbach's alpha for all five constructs is above the lower limit of acceptability, 0.70 . This confirms that the measurement set used in the study was reliable.

\section{Validity}

A factor analysis can also be performed to assess the discriminant validity of the measuring instrument (Rootman 2006:128). As stated earlier, the rotation method used in this research was the Varimax with Kaiser Normalisation. Table 2 reflects the rotated factor analysis results of the variable's conflict handling and two-way communication.

\section{Multiple regression analyses results Influence of the independent variables on the intervening variable}

Multiple regression analysis was performed in order to assess the relationship between the independent variables (two-way communication and conflict handling) and the intervening variable (CRM). The results are reflected in Table 3.

Table 3 indicates that one of the independent variables, Conflict handling, exerted a statistically significant positive influence on the intervening variable (CRM), whilst two-way communication exerted a statistically significant negative influence on the intervening variable (CRM). The researcher relied on a $95 \%$ level of confidence, therefore a $p$-value of less than or equal to 0.05 implied that it was highly unlikely that the results were due to chance alone, according to the Independent Sample T-test. This implied that the hypotheses are accepted and the null hypotheses are rejected. The relationship between two-way communication and CRM is significant at $p=0.014$ and the relationship between conflict
TABLE 1: Reliability statistics.

\begin{tabular}{lc}
\hline Constructs & Cronbach's Alpha \\
\hline Two-way communication & 0.906 \\
Conflict handling & 0.882 \\
CRM & 0.941 \\
Loyalty & 0.970 \\
CRM and its influence on loyalty & 0.918 \\
\hline
\end{tabular}

Source: Developed for this research

CRM, Customer Relationship Management.

handling and CRM is significant at $p=0.000$. The null hypotheses $\mathrm{HO}^{1}$ and $\mathrm{HO}^{2}$ are therefore rejected.

The hypothesis, $\mathrm{HA}^{1}$, which states that there is a relationship between the perceived two-way communication of a longterm insurance organisation and CRM at the organisation in South Africa, and hypothesis $\mathrm{HA}^{2}$, which states that there is a relationship between the perceived conflict handling by a long-term insurance organisation and CRM at the organisation in South Africa, are therefore accepted.

\section{Influence of the intervening variable on the dependent variable}

Multiple regression analysis was performed for the purpose of assessing the relationship between the intervening variable (CRM) and the dependent variable (customer loyalty). The results are reflected in Table 4.

Table 4 indicates that the intervening variable (CRM) positively influenced the dependent variable (customer loyalty). The relationship between CRM and customer loyalty is significant at $p=0.000$.

This relationship implies that if the long-term insurance organisation successfully maintained relationships with its customers, intentional customer loyalty at the long-term insurance organisation would increase. Table 4 indicates that the intervening variable in the multiple regression analysis explained $80.2 \%$ of the variance $\left(R^{2}\right)$ in the dependent variable. In other words, it can be said that $80.2 \%$ of a possible change in the level of customer loyalty in the long-term insurance organisation is caused by CRM. Table 4 further indicates that one unit increase in CRM will increase customer loyalty by $89.5 \%$ when considering Beta. The null hypothesis $\mathrm{HO}^{3}$, which states that there is no relationship between CRM and intentional customer loyalty at a long-term insurance

TABLE 2: Exploratory rotated factor analysis results.

\begin{tabular}{|c|c|c|c|}
\hline Number & Items & $\begin{array}{c}\text { Conflict } \\
\text { handling }\end{array}$ & $\begin{array}{c}\text { Two-way } \\
\text { communication }\end{array}$ \\
\hline 1 & My relationship with Liberty Life depends on whether it compensates me for mistakes made. & .729 & .082 \\
\hline 2 & My relationship with Liberty Life will be better if it apologises for problems that arose. & .715 & .260 \\
\hline 3 & My relationship with Liberty Life will be better if it identifies problems even before they occur and corrects them. & .695 & .302 \\
\hline 4 & If Liberty Life keeps me informed on how they are resolving problems that occurred, I would feel more positive towards it. & .662 & .125 \\
\hline 5 & My relationship with Liberty Life depends on whether the information it provides is always accurate. & .297 & .698 \\
\hline 6 & My relationship with Liberty Life can improve if the communication that I receive from it is easy to understand. & .250 & 679 \\
\hline 7 & My relationship with Liberty Life depends on whether it makes and fulfils promises. & .246 & .656 \\
\hline 8 & My relationship with Liberty Life depends on whether it tailor-makes its communication to suit my needs. & .236 & .609 \\
\hline
\end{tabular}

Source: Developed for this research 
organisation in South Africa, is rejected. The hypothesis $\mathrm{HA}^{3}$, which states that there is a relationship between CRM and intentional customer loyalty at a long-term insurance organisation in South Africa, is accepted.

The results of the findings of the empirical investigation are presented in Figure 2.

TABLE 3a: Influence of the independent variables on customer relationship management.

\begin{tabular}{lcccccc}
\hline Framework & \multicolumn{2}{c}{ Squares } & DF & $\begin{array}{c}\text { Mean } \\
\text { Square }\end{array}$ & $F$-value & Sig. \\
\cline { 2 - 4 } & Sum & $\boldsymbol{R}^{2}$ & & & & \\
\hline Regression & 320.380 & - & 4 & 80.095 & 79.266 & 0.000 \\
Residual & 251.604 & - & 249 & 1.010 & - & - \\
\hline Total & $\mathbf{5 7 1 . 9 8 4}$ & $\mathbf{0 . 5 6 0}$ & $\mathbf{2 5 3}$ & - & - & - \\
\hline
\end{tabular}

Source: Developed for this research

CRM, Customer Relationship Management; DF, disk free; Sig. significance.

TABLE 3b: Influence of the independent variables on customer relationship TABLE 3b: Influe
management.

\begin{tabular}{lccc}
\hline Framework & $\begin{array}{c}\text { Standardised } \\
\text { coefficients, Beta }\end{array}$ & T & Sig. \\
\hline (Constant) & - & -2.121 & 0.035 \\
Two-way communication & -0.190 & -2.478 & 0.014 \\
Conflict handling & 0.517 & 8.563 & 0.000 \\
\hline
\end{tabular}

Source: Developed for this research

CRM, Customer Relationship Management; DF, disk free; Sig. significance.

TABLE 4a: Influence of the intervening variable on customer loyalty.

\begin{tabular}{|c|c|c|c|c|c|c|}
\hline \multirow[t]{2}{*}{ Framework } & \multicolumn{2}{|c|}{ Squares } & \multirow[t]{2}{*}{ DF } & \multirow{2}{*}{$\begin{array}{l}\text { Mean } \\
\text { Square }\end{array}$} & \multirow[t]{2}{*}{$F$-value } & \multirow[t]{2}{*}{ Sig. } \\
\hline & Sum & $R^{2}$ & & & & \\
\hline Regression & 503.073 & - & 1 & 503.073 & 1019.925 & 0.000 \\
\hline Residual & 124.298 & - & 252 & 0.493 & - & - \\
\hline Total & 627.371 & 0.802 & 253 & - & - & - \\
\hline
\end{tabular}

Source: Developed for this research

CRM, Customer Relationship Management; DF, disk free; Sig. significance.

TABLE 4b: Influence of the intervening variable on customer loyalty.

\begin{tabular}{lccc}
\hline Framework & $\begin{array}{c}\text { Standardised } \\
\text { coefficients, Beta }\end{array}$ & T & Sig. \\
\hline (Constant) & - & 1.691 & 0.092 \\
CRM & 0.895 & 31.936 & 0.000 \\
\hline
\end{tabular}

Source: Developed for this research

CRM, Customer Relationship Management; DF, disk free; Sig. significance.

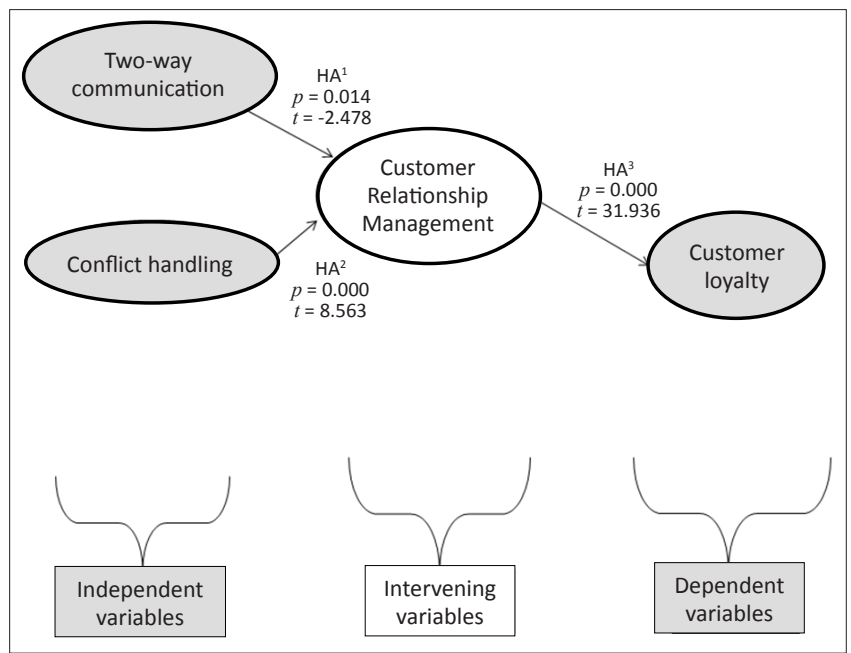

Source: Developed for this research

FIGURE 2: Empirical framework modified.

\section{Managerial implications}

The empirical results imply that a long-term insurance organisation can improve and maintain its relationships between the organisation and customers if the organisation communicates information to customers in an efficient and accurate manner, as well as listening to its customers and skilfully handling potential and manifested conflicts. Furthermore, it is clear that if the conflict handling skills exhibited by a long-term insurance organisation are apparent, customers require less two-way communication to improve the quality of the relationship.

\section{Two-way communication}

The focus of a long-term insurance organisation should be on attracting and retaining customers through cooperation, trust, commitment and the sharing of information between the parties in the relationship. In the ongoing relationship with the customer, a long-term insurance organisation is required to communicate with the customer, and the customer is expected to listen. Both parties in a relationship have to communicate with each other. A long-term insurance organisation can nurture the loyalty of customers by providing accurate information that is easy to understand and that is tailored to address the customers' needs, and finally by making and fulfilling promises. The organisation should ensure that its sales force discloses all necessary information to the customer in a clear, understandable and accurate way at the point of sale. Once the policy is in force, communicating to the customer in a timely, accurate and understandable manner, and ensuring that customers are promptly informed about key changes to their policies and its likely returns, should be a priority for a long-term insurance organisation. This can be done through, for example, an annual anniversary letter being sent to all customers. A long-term insurance organisation must ensure that, once the conflict handling aspect has firmly been imbedded, it reduces its two-way communication with customers to a customerdesired level.

\section{Conflict handling}

Customers will be loyal to a long-term insurance organisation if it handles customer complaints and other conflicts satisfactorily. It is therefore important that effective conflict resolution mechanisms are not only in place, but are proactive, so as to pre-empt potential sources of conflict and address them before problems manifest. The organisation should also ensure the effectiveness of its Customer Relations Department in order to ensure that reactive solutions are marshalled both decisively and in time to resolve problems and protect customers from avoidable losses. A long-term insurance organisation must be willing to discuss problems with customers in an open manner. The way in which conflicts are handled by a long-term insurance organisation will have a direct influence on customer loyalty. The degree to which the organisation and its customers in the relationship engage in conflict handling processes will depend on their 
prior satisfaction with the relationship, the magnitude of the investment in the relationship, and the alternatives that each party has.

A long-term insurance organisation should make it as easy as possible for customers to complain. Written complaints should only be required if they are necessary for legal reasons. It should inform customers of failures or mistakes, and if the organisation cannot correct them immediately, they should inform the customer when the problem will be rectified. A long-term insurance organisation should compensate customers immediately, and where immediate compensation cannot be given, no unnecessary delays should be allowed. A lost profitable customer has a greater effect on the longterm profitability of a long-term insurance organisation than overcompensation. The organisation should measure their conflict handling regularly through the customers' eyes, and not use a long-term insurance organisation's yardstick. A long-term insurance organisation can also design specific training sessions for employees, with a view to emphasising the conflict handling aspect. Managers should only employ staff members who can work with difficult customers.

\section{Relationship between the intervening variable, customer relationship management, and the dependent variable, customer loyalty}

A long-term insurance organisation should develop training sessions that inform employees of the core CRM processes, namely, customer acquisition, customer retention and customer development. Just as a customer acquisition strategy aims to increase the customer base, the focus of customer retention is to keep a high proportion of current customers by reducing customer defections. The organisation should launch a customer development strategy which aims to increase the value of retained customers. A long-term insurance organisation should aim to retain and develop loyal customers by communicating both timeously and accurately, and must resolve conflicts in a manner that will eliminate unnecessary loss of and inconvenience to customers.

In order to maintain relationships with customers and to retain loyal customers, a long-term insurance organisation may give special benefits to loyal customers, for example lowering policy charges when new policies are entered into, and charging less administrative fees for managing customers' investments. It is clear from the empirical studies that only one unit increase in CRM at the organisation can increase customer loyalty by $89.5 \%$. A long-term insurance organisation should ensure that CRM, and therefore customer loyalty, increases by delivering high quality and high value products and services. The policies and other services should deliver on promises. A long-term insurance organisation should train employees to understand that every single contact with a customer must count. Loyalty schemes equivalent to Discovery's Vitality Programme could also be introduced by the organisation. This loyalty programme would not only contribute to obtaining a bigger share of the customer's wallet, but could also be used to obtain more information about the customers.

A long-term insurance organisation must deliver excellent customer services. The particular experience that a customer has with customer service will influence how the customer feels about the organisation. A long-term insurance organisation should always do the unexpected and that is to treat customers well. Unfortunately, most customers today expect to be ignored or mistreated. The organisation can request senior managers to phone clients personally to thank them for their business or give reasons for a mistake made, and to indicate what measures the organisation is taking in order to rectify the mistake. It should also use its customer database to maximise the personalisation of offers to customers. Should an organisation be able to implement the recommendations, customer loyalty will increase, which will lead to higher profits and will give the organisation a sustainable competitive advantage.

\section{Conclusions}

It is important to note that, although the research was conducted in four major centres in South Africa at one long-term insurance organisation, the findings and recommendations may be applicable to other long-term insurance organisations in South Africa due to the uniformity of services on offer. This research succeeded in identifying a list of dimensions that underpin CRM and which can predict customer loyalty at a long-term insurance organisation in South Africa. Managers aiming to build a loyal customer base should concentrate on the issue of two-way communication and conflict handling. Strategies to improve how the longterm organisation communicates with customers and how it obtains information concerning the customers' needs, as well as how conflicts between the customer and the organisation are dealt with during a service failure, should be implemented. These strategies, when implemented, will increase customer loyalty, which in turn will lead to increased profitability of the organisation and sustainability of the organisation's future.

\section{Acknowledgments Competing interests}

The authors declare that they have no financial or personal relationship(s) which may have inappropriately influenced them in writing this paper.

\section{Authors' contributions}

L.D.P. was the Legal Compliance Manager at a prominent life insurance organisation in Johannesburg at the time of the research. He played a pivotal role in executing the research and made a pertinent contribution to improving the customer management initiatives of the organisation. M.R-L. wrote the manuscript and refined the findings to develop workable strategies for the organisation. This enhanced the value of the research for due to its applicability to industries across the board. 


\section{References}

Baran, R.J., Galka, R.J. \& Strunk, D.P., 2008, Principles of customer relationship management, Thomson South-Western, Mason.

Berndt, A., Du Plessis, L., Klopper, H.B., Lubbe, I. \& Roberts-Lombard, M., 2009, Starting out in marketing, Future Vision Business Consultants, Roodepoort.

Botes, J.A., 2008, 'Customer loyalty and employee enthusiasm: an eclectic paradigm for strategic sales improvement at MB Silicon Systems', unpublished Master's dissertation, Milpark Business School, Johannesburg.

Buttle, F., 2004, Customer Relationship Management, concepts and tools, Elsvier Butterworth-Heinemann, Burlington.

Datamonitor, 2011a, Country analysis report, South Africa, n.p.: Datamonitor.

Datamonitor, 2011b, South Africa life insurance, n.p.: Datamonitor.

Du Plessis, P.J., Jooste, C.J. \& Strydom, J.W., 2005, Applied strategic marketing, 2nd edn., Heinemann, Sandton.

Egan, J., 2004, Relationship marketing, exploring relational strategies in marketing, 2nd edn., Pearson Education Limited, Essex.

Fuxiang, L.I.U. \& Yuhui, Y.O.U., 2011, 'Study and Explores on CRM based on the Supply chain integration', Management Science and Engineering 5(1), 1-9.

Grönroos, C., 2003, Service management and marketing a customer relationship management approach, 2nd edn., Wiley, West Sussex.

Gummesson, E., 2003, Total relationship marketing, 2nd edn., Butterworth Heinemann, Oxford.

Hair, J.F. (Jr), Anderson, R.E., Tatham, R.L. \& Black, W.C., 1998, Multivariate dato analysis, 5th edn., Prentice-Hall, Upper Saddle River, N.J.

Hakkio, S. \& Laaksonen, P., 1998, 'Relationships in marketing channels: Examining communication abilities through cognitive structures', Psychology \& Marketing 15(3), 215-240. http://dx.doi.org/10.1002/(SICl)15206793(199805)15:3<215::AID-MAR2>3.0.CO;2-D

Harwood, T., Garry, T. \& Broderick, A., 2008, Relationship marketing - perspectives, dimensions and context, McGraw-Hill, London.

Hasounet, A.B.I. \& Alqeed, M.A., 2010, 'Measuring the Effectiveness of E-mail Direct Marketing in Building Customer Relationship', International Journal of Marketing Studies 2(1), 48-64.

Iglesias, O., Sauquet, A. \& Montana, J., 2011, 'The role of corporate culture in relationship marketing', European Journal of Marketing 45(4), 631-650. http:// dx.doi.org/10.1108/03090561111111361

Kotler, P. \& Keller, K.L., 2006, Marketing Management, 12th edn., Pearson Prentice Hall, New Jersey.

Leverin, A. \& Liljander, V., 2006, 'Does relationship marketing improve customer relationship satisfaction and loyalty?', International Journal of Bank Marketing 24(4), 232-251. http://dx.doi.org/10.1108/02652320610671333

Life Offices Association, 2007, Half-yearly statistics - circular 60/2007, Life Offices Association, Cape Town.
Lusch, R.F. \& Vargo, S.L., 2011, 'Service-dominant logic: a necessary step', European Journal of Marketing 45(7/8), 1298-1309. http://dx.doi. org/10.1108/03090561111137723

Morgan, R.M. \& Hunt, S.D., 1994, 'The Commitment-Trust Theory of Relationship Marketing', Journal of Marketing 58, July, 20-38. http://dx.doi. org $/ 10.2307 / 1252308$

Ndubisi, N.O., 2007, 'Relationship marketing and customer loyalty', Marketing Intelligence \& Planning 25(1), 98-106.

Ndubisi, N.O. \& Chan, K.W., 2004, 'Relationship marketing keystones and impacts on relationship quality, customer satisfaction, and customer loyalty', proceedings of AIMS International Conference on Management, India, December 28-31, 562569. http://dx.doi.org/10.1108/02634500710722425

Ndubisi, N.O. \& Wah, C.K., 2005, 'Factorial and discriminant analyses of the underpinnings of relationship marketing and customer satisfaction International Journal of Bank Marketing 23(7), 542-557. http://dx.doi. org/10.1108/02652320510629908

Robinson, L., Neeley, S.E. \& Williamson, K., 2011, 'Implementing service recovery through customer relationship management: identifying the antecedents', Journal of Services Marketing 25(2), 90-100. http://dx.doi org/10.1108/08876041111119813

Rootman, C., 2006, 'The influence of customer relationship management on the service quality of banks', unpublished Masters dissertation, Nelson Mandela Metropolitan University, Port Elizabeth.

Rootman, C., 2011, 'An international comparative study on the relationship marketing and customer retention of retail banks: Lessons for South Africa', unpublished Doctoral thesis, Nelson Mandela Metropolitan University, Port Elizabeth.

Sauers, A.C., 2008, Effective customer relationship management, Cambria Press, New York.

Strachan, L., 2010, 'Investigating the influence of Customer Relationship Management on customer loyalty at selected short term insurance providers in Gauteng', BCom On customer loyalty at selected short term insurance providers in
(Honours) Dissertation, University of Johannesburg, Johannesburg.

Strachan, L. \& Roberts-Lombard, M., 2010, 'Customer retention through customer relationship management: The exploration of two-way communication and conflict handling', African Journal of Business Management 5(9), 3487-3496.

Terblanche, N.S., 2003, 'Relationship marketing, consumer exchange situations and loyalty programmes: A review', Management Dynamics 12(4), 27-38.

Toriani, S. \& Angeloni, M.T., 'CRM as a support for knowledge management and customer relationship', Journal of Information Systems and Technology Management 8(1), 87-108.

Vargo, S.L., 2011, 'Market systems, stakeholders and value propositions. Toward a service-dominant logic-based theory of the market', European Journal of Marketing 45(1/2), 217-222. http://dx.doi.org/10.1108/03090561111095667

Ward, T. \& Dagger, T.S., 2007, 'The complexity of relationship marketing for service customers', Journal of Services Marketing 21(4), 281-290. http://dx.doi. org/10.1108/08876040710758586

Wu, L., 2011, 'Inertia: Spurious loyalty or action loyalty?', Asia Pacific Management Review 16(1), 31-50.

Zeithaml V.A., Bitner M. \& Gremler D.D. 2006. Services marketing: Integrating customer focus across the firm, 7th edn., McGraw-Hill, New York. 